\title{
Erratum to: Expressivism and realist explanations
}

\section{Camil Golub ${ }^{1}$}

\section{Erratum to: Philos Stud DOI 10.1007/s11098-016-0764-6}

In the original publication of the article, the reference citation in footnote 15 was incorrectly published as "Blackburn (1993, p. 98), his italics". The corrected reference citation should read as "Blackburn (1996, p. 86), his italics".

The reference to the citation, "Blackburn (1996)," is given here.

\section{Reference}

Blackburn, S. (1996). Securing the nots: Moral epistemology for the quasi-realist. In W. SinnottArmstrong \& M. Timmons (Eds.), Moral knowledge? New readings in moral epistemology. Oxford: Oxford University Press.

The online version of the original article can be found under doi:10.1007/s11098-016-0764-6.

Camil Golub

camil.golub@nyu.edu

1 Department of Philosophy, New York University, 5 Washington Place, New York, NY 10003, USA 